\title{
AUTOMATION DETECTION OF DRIVER FATIGUE USING VISUAL BEHAVIOR VARIABLES
}

\author{
YONGGANG WANG ${ }^{1 *}$, JINGFENG MA $^{2}$
}

\begin{abstract}
To examine the correlation of driver visual behaviors and subjective levels of fatigue, a total of 36 commercial drivers were invited to participate in $2-\mathrm{h}, 3-\mathrm{h}$, and 4-h naturalistic driving tests during which their eye fixation, saccade, blinking variables, and self-awareness of their fatigue levels were recorded. Then, one-way ANOVA was applied to analyze the variations of each variable among different age groups over varying time periods. The statistical analysis revealed that driving duration had a significant effect on the variation of visual behaviors and feelings of fatigue. After $2 \mathrm{~h}$ of driving, only the average closure duration value and subjective level of fatigue had an increase of one-fifth or more. After $4 \mathrm{~h}$ of driving, however, all these variables had a significant change except for the number of saccades and pupil diameter measurements. Particularly, driver saccadic eye movement was more sensitive to driving fatigue, and the elderly were more likely to be affected by the duration of the drive. Finally, a predictor of driver fatigue was determined to detect the real-time level of fatigue and alert at the critical moment.
\end{abstract}

Keywords: driving duration, visual behaviors, fatigue level, Stanford Sleepiness Scale, predictor of driver fatigue

\section{INTRODUCTION}

Nowadays, driving fatigue is a major cause of road traffic fatalities and injuries in China, and it was estimated that as much as $15 \%$ of all automobile accidents were caused directly or partially by driving fatigue [1]. Commercial drivers have to stay focused for long hours behind the wheel, which makes

\footnotetext{
${ }^{1}$ Asso. Prof., PhD., Chang'an University, School of Highway, P.O. Box 487, Middle Section of South 2 Ring Rd., Xi'an 710064, Shaanxi, China, ${ }^{*}$ corresponding author, e-mail: wangyg@chd.edu.cn

${ }^{2}$ MSc., Chang'an University, School of Highway, P.O. Box 487, Middle Section of South 2 Ring Rd., Xi'an 710064, Shaanxi, China, e-mail: 1315549895@qq.com
} 
them easily fatigued [2], and, accordingly, it is necessary to detect the real-time levels of driver fatigue and alert them at critical moment for crash avoidance while in motion.

In many previous studies, a great number of researchers have used visual signals such as degree of eye opening, blink duration, gaze, yawning, etc., to assess the level of driving fatigue [3-6]. Meanwhile, some others have explored physiological measures such as brain waves, heart rate, breathing, body temperature, and blood pressure to examine driver fatigue [7-9]. Furthermore, the variation of driving behaviors (e.g., steering wheel movements, deviation of lateral position, acceleration/deceleration) is also frequently used in identifying driver fatigue $[6,10]$.

To our best knowledge, driver fatigue accumulates gradually with very long continuous driving periods without rest breaks, and thus the level of driver fatigue can be measured through the variation of visual behavior variables. Therefore, a predictor of driver fatigue is proposed herein.

\section{MethodS}

Thirty-six professional drivers ( 8 female) with normal vision and good health from Jinan, China were originally recruited to take part in the driving test. Each of the participants had at least 5 years of driving experience, and refrained from alcohol/drugs for three days prior to the test.

In driving, drivers depend on eye fixation, saccade, and blinking behaviors to detect traffic conditions, and these were significantly correlated with fatigue [5], so four fixation variables (pupil diameter, $\mathrm{mm}$; number of on-road fixations, times/s; on-road fixation duration, $\mathrm{s}$; deviation of visual search angle, ${ }^{\circ}$ ), three saccade variables (number of saccade, times/s; saccade speed, \% $/ \mathrm{s}$; saccade amplitude, ${ }^{\circ}$ ), and three blinking variables (blink frequency, times/s; blink duration, s; closure duration, s) were collected with the Smart Eye Pro 6.0 at a frequency of $200 \mathrm{HZ}$.

In addition, the Stanford Sleepiness Scale (SSS) [11] with seven refined categories was proposed to quantify the drivers' subjective fatigue feelings, as shown in Table 1. 
Table 1. The Stanford Sleepiness Scale (SSS)

\begin{tabular}{|l|c|}
\hline \multicolumn{1}{|c|}{ Level of sleepiness/fatigue } & Scale Rating \\
\hline Feeling active, vital, alert, or wide awake & 2 \\
\hline $\begin{array}{l}\text { Functioning at high levels, but not at peak; able to } \\
\text { concentrate }\end{array}$ & 3 \\
\hline Awake, but relaxed; responsive, but not fully alert & 4 \\
\hline Somewhat foggy, let down & 5 \\
\hline Foggy; losing interest in remaining awake; slowed down & 6 \\
\hline Sleepy, woozy, fighting sleep; prefer to lie down & \multicolumn{2}{|c|}{7} \\
\hline $\begin{array}{l}\text { No longer fighting sleep, sleep onset soon; having } \\
\text { dream-like thoughts }\end{array}$ & 2 \\
\hline
\end{tabular}

The real driving tests were conducted in March 2015 on three routes (route a: $157 \mathrm{~km}$ from the Ganggou Interchange GG of Jinan to the Xinzhuang Interchange XZ of Xishui, 2-hour driving; route b: $216 \mathrm{~km}$ from the Xizhuang Interchange XZ of Yishui to the South Chengyang Interchange SCY of Qingdao, 3-h driving; route c: $334 \mathrm{~km}$ from the South Chengyang Interchange SCY of Qingdao to the North Jinan Interchange NJN of Jinan, 4-h driving) in Shandong, China, as shown in Fig.1.

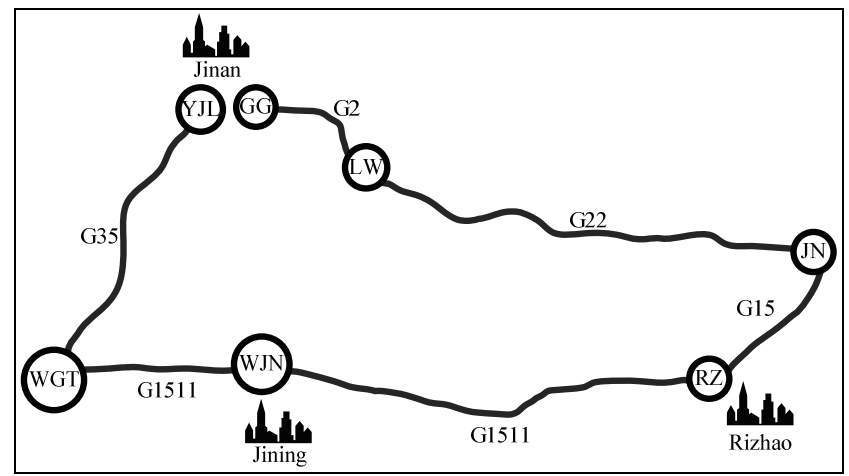

Fig. 1 Illustration of driving test routes in Shandong, China.

Each participant was asked to complete the 2-, 3-, and 4-h long driving tasks along routes a, b, and c, respectively, and they were required to complete one driving test task in one day. At the end of each route the participant's visual behaviors and self-reported fatigue feelings were recorded prior to any rest. 
In the data-processing stage, the 36 participants were divided into four groups by age, namely ' $<30$ ' (7 persons), ' 30 - 40' (14 persons), ' 40 - 50’ (10 persons), and ‘ $>50$ ’ (5 persons). One-way Analysis of Variance (ANOVA) was introduced to analyze each objective or subjective variable's change rate of a certain age group at a significance level of 0.05 , compared to its original (baseline) value determined in the training session before the driving task.

\section{RESULTS}

\subsection{FIXATIONS}

Figure 2 shows the change of the driver's eye fixation behaviors of different age groups over the duration of driving. For drivers of different ages, their fixation behavior variables vary differently after finishing the same task of continuous driving. On the other hand, the longer the continuous driving, the wider the variation of the driver's fixation behavior.
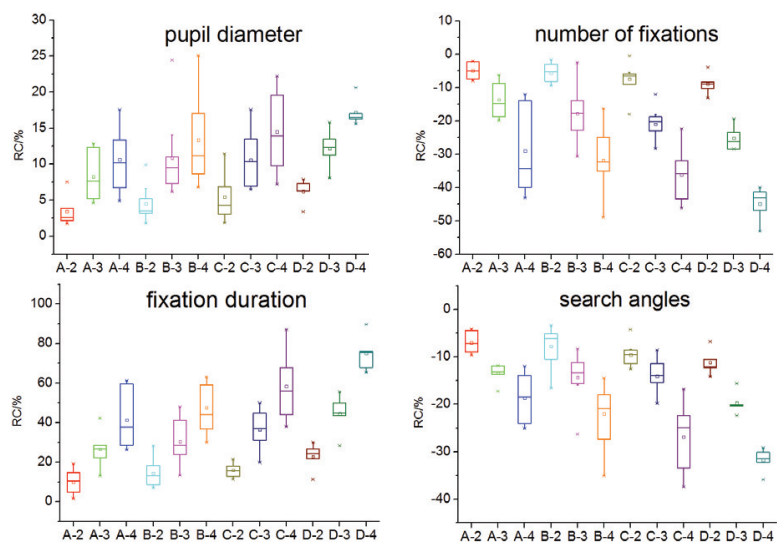

Fig. 2 Rate of change of driver's eye fixation behavior

After finishing the 2-h driving task, as shown in Fig. 1, all four fixation variables of the ' $<30$ ' group showed no obvious changes in comparison to the baseline value before the driving test, but the average on-road fixation duration value of the ' $>50$ ' group $(F=20.306, p=0.002)$ increased significantly. For the 4-h driving test, the average on-road fixation duration value $(F=30.523, p<$ $0.001)$, average number of fixations on-road $(F=14.872, p=0.002)$, and average deviation of the 
search angle $(F=25.293, p<0.001)$ of the ' $>50$ ' group had a significant change of $58.80 \%,-36.67 \%$, and $-26.94 \%$, respectively, while these three variables of the ' $<30$ ' group changed less in value.

\subsection{SACCADES}

Figure 2 presents the variations of the eye saccade behaviors of professional drives among the four groups after different driving tasks. The variation of eye saccade behaviors is obvious in comparison to the baseline values over time. Furthermore, for the older professional drivers, their variation of all three saccade variables increases with the increase of continuous driving time.
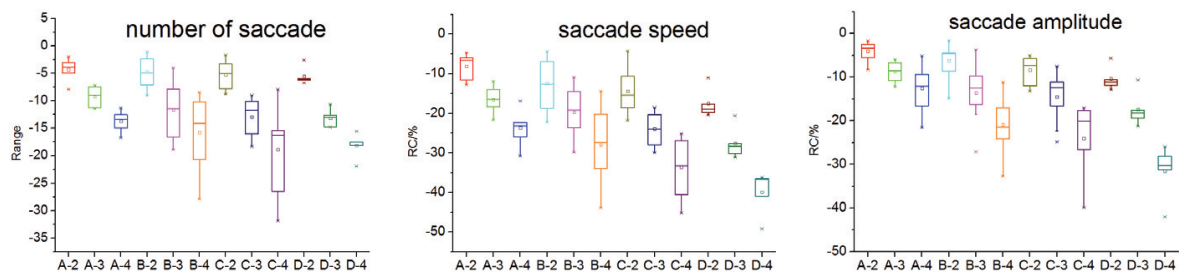

Fig. 3 Rate of change of driver's eye saccade behavior

For example, the average saccade number of the ' 30 - 40' group dropped by $16.69 \%$ and $28.06 \%$, respectively, after 3-h and 4-h driving, while it decreased by only $12.32 \%$ after 2 -h driving. For the ' $<30$ ' group, all three saccade indicators did not decrease significantly after 2- and 3-h-long driving, as shown in Table 2, but after four hours of continuous driving the average saccade speed value decreased greatly $(F=36.622, p<0.001)$ by more than one-fifth, and the other two indicators showed no significant decrease. For the ' $>50$ ' group, meanwhile, the decrease of this variable expanded to $17.57 \%, 27.60 \%$, and $39.70 \%$, respectively, after 2-h, 3-h, and 4-h continuous driving.

\subsection{BLINK}

Figure 4 exhibits the variations of a driver's eye blinking behaviors. It's clear that the changes of eye blinking behaviors vary greatly among different age groups over time. In the 2-h driving test, an average eye's closure duration value for the ' $<30$ ' group increased by $21.55 \%(F=11.762, p=0.005)$, and it expanded to $34.80 \%$ for the ' $>50$ ' group $(F=87.341, p<0.001)$. 


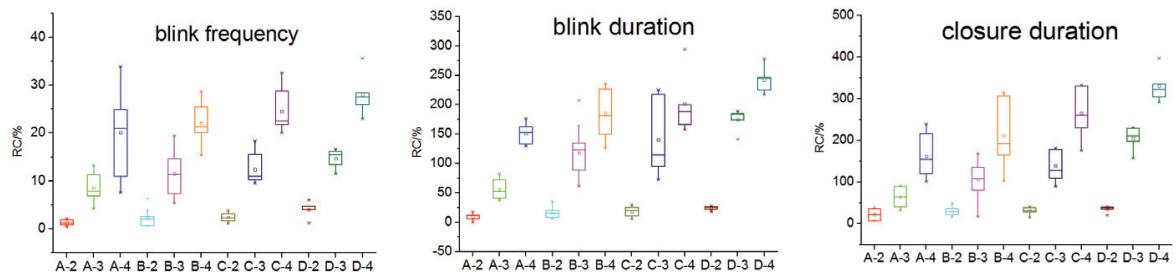

Fig. 4 Rate of change of driver's eye blinking behavior

In view of the eye's average blink duration, its average value for the ' $<30$ ' group has a statistically significant increase - by $10.00 \%(F=87.341, p<0.001), 56.67 \%(F=87.341, p<0.001)$, and $150.83 \%(F=87.341, p<0.001)$, respectively, after 2-h, 3-h, and 4-h driving tasks. As expected, its increase for the ' $>50$ ' group expanded to $23.96 \%(F=6.080, p=0.039), 175.00 \%(F=78.509, p<$ $0.001)$, and $240.63 \%$ ( $F=304.920, p<0.001)$, respectively, after finishing the same driving tasks.

\subsection{SUBJECTIVE LEVEL OF FATIGUE}

As expected, MANOVA revealed that there was significant difference between different groups in the variations of subjective fatigue level (Fig. 5). For ' $<30$ ' group, it was averagely scored as 2.83 $(F=3.636, p=0.086), 3.83(F=22.727, p<0.001)$ and $4.17(F=32.727, p<0.001)$, respectively, after 2-h, 3-h and 3-h driving, accounting for an increase of 37.83\%, 89.51\% and $123.96 \%$.

Similar results were also found among the other three groups, respectively, but the change rate increased substantially. For ' 40 - 50' group, for example, the average value increased from 1.70 to $2.56(F=13.474, p=0.002)$ for 2 -h driving, $3.56(F=60.842, p<0.001)$ for 3 -h driving and $4.22(F$ $=132.250, p<0.001$ ) for 4-h driving, respectively, with an increase of about $50-150 \%$.

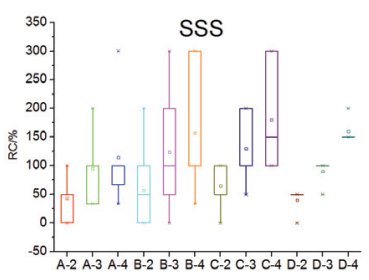

Fig. 5 Rate of change of driver's subjective level of fatigue 


\subsection{PREDICTOR OF DRIVER FATIGUE}

Table 2 presents the predictor of driver fatigue via visual behaviors under $95 \%$ significance levels where the model's goodness-of-fit indexes, $R^{2}$, are $0.875,0.858,0.953$, and 0.995 , respectively, with all $p<0.001$, for the '<30', ' $30-40$ ', ' $40-50$ ', and ' $>50$ ' groups.

Table 2. Predictor of driver fatigue via visual behavior variables

\begin{tabular}{|c|c|c|c|c|c|c|c|c|}
\hline \multirow{2}{*}{ Variable } & \multicolumn{2}{|c}{$<30$} & \multicolumn{2}{|c|}{$30-40$} & \multicolumn{2}{c|}{$40-50$} & \multicolumn{2}{c|}{$>50$} \\
\cline { 2 - 9 } & estimate & t-stat & estimate & t-stat & estimate & t-sta t & estimate & t-stat \\
\hline \multirow{2}{*}{ Constant } & -12.582 & -0.388 & $-66.005^{* *}$ & -3.444 & $-30.566^{*}$ & -2.135 & $-45.015^{*}$ & -2.997 \\
\hline BF & 3.465 & 1.162 & -3.940 & -1.443 & -5.847 & -1.999 & -0.350 & -0.284 \\
\hline BD & -0.521 & -0.833 & -0.276 & -0.985 & 0.073 & 0.415 & -0.174 & -0.783 \\
\hline CD & -0.357 & -0.546 & 0.202 & 0.663 & 0.152 & 0.650 & 0.125 & 0.646 \\
\hline PD & 2.033 & 0.338 & $5.807^{*}$ & 2.510 & $3.877^{*}$ & 2.127 & 4.389 & 1.497 \\
\hline NS & -3.447 & -0.553 & -2.682 & -1.095 & $-3.976^{*}$ & -2.094 & 1.541 & 0.651 \\
\hline SS & -5.430 & -1.321 & $-4.692^{*}$ & -2.423 & -1.269 & -0.810 & -2.336 & -2.079 \\
\hline SA & -9.420 & -1.991 & $-5.400^{*}$ & -2.055 & -2.636 & -1.304 & 0.166 & 0.125 \\
\hline NF & -1.194 & -0.519 & 0.835 & 0.552 & 0.902 & 0.778 & 0.096 & 0.100 \\
\hline FD & -1.614 & -0.848 & -0.469 & -0.394 & $2.065^{*}$ & 2.703 & 0.231 & 0.343 \\
\hline DS & $4.634^{*}$ & 2.283 & -0.653 & -0.227 & 0.949 & 0.453 & -2.120 & -1.349 \\
\hline$R^{2}$ & 0.875 & 0.858 & 0.953 & & 0.995 \\
\hline
\end{tabular}

${ }^{*} p$-value $<0.05,{ }^{* *} p$-value $<0.01, \mathrm{BF}=$ blink frequency, $\mathrm{BD}=$ blink duration, $\mathrm{CD}=$ closure duration, $\mathrm{PD}=$ pupil diameter, NS = number of saccades, $\mathrm{SS}=$ saccade speed, $\mathrm{SA}=$ saccade amplitude, $\mathrm{NF}=$ number of fixations on-road, $\mathrm{FD}=$ on-road fixation duration, $\mathrm{DS}=$ deviation of search angles

Clearly, this model characterizes the relationship between the variations in driver fatigue and ten visual behavior variables from baseline values before the test; thus it is easy to assess driver real-time fatigue levels while driving plus the baseline value recorded in the personnel 'health' database. 


\section{CONCLUSIONS AND DisCUSSIONS}

Driver fatigue contributes significantly to the occurrence of road traffic accidents, especially for those engaged in long-distance commercial transport, and so how we identify driver fatigue while driving is urgently important for preventing automobile crashes and reducing injury severities [12]. This study investigated the association between the variation of driver visual behaviors (e.g., fixation, saccade, blinking) and subjective feelings of fatigue while performing the 2-h, 3-h, and 4-h continuous driving tasks, and determined a predictor of driver fatigue level.

The results indicate that the variation of driver fatigue levels is positively correlated with the change of pupil diameter, fixations durations, and blinking behaviors (e.g., blink frequency, blink duration, closure duration), and negatively related to the change of the number of fixations, deviations of the visual search angle, and saccade behaviors (i.e., saccade number, saccade speed and saccade amplitude), which are consistent with the results reported in our previous research $[5,6]$.

This test also shows that the duration of continuous driving has a significant influence on driver visual behaviors and fatigue levels. For drivers aged between 30 and 40 years, the average closure duration value increased from $0.78 \mathrm{~s}$ to $2.40 \mathrm{~s}$ after the 4-h driving task, accounting for a statistically sharp increase of $209.12 \%$, and, meanwhile, the average driver self-reported level of fatigue grew by $123.96 \%$, in line with the variation of visual behaviors. This result is consistent with the findings of Hjälmdahl et al. in 2017 [13]. The change rate of all variables varied greatly across age groups, even after the same driving task. As expected, the elderly are more sensitive to fatigue. This is mainly due to the fact that they are more susceptible to become fatigued while driving carefully. Similar findings have also been reported in our previous research $[5,6]$.

Our results highlight the importance of limiting the continuous driving time and the total number of driving hours per day and emphasizing rest time, especially for those engaged in long-distance commercial transport, where older drivers should be given a longer period of rest. Strict traffic laws and regulations should be implemented and violators should be seriously prosecuted. Of course, drivers should be educated to recognize the harmfulness of fatigue and keep themselves from driving while fatigued. These suggestions are in good agreement with the results of Bener et al. and Kureckova et al. in 2017 [14, 15]. The results also provide a useful tool of assessing the potential level of driver fatigue and giving the driver an alert at rest moments.

Arguably, this study has some methodological limitations. First, the number of participants invited was small, and may not be a representative sample of the entire population of Chinese drivers. Secondly, driver eye movement variables are more sensitive to the surrounding environmental effects, 
and, consequently, the collected data may potentially contain inaccuracies; such potential conflicts should be processed before analyzing test results. Finally, the levels of fatigue acquired through selfreporting may not be reliable due to incorrect judgment.

\section{ACKNOWLEDGEMENT}

This research is financially supported by the Natural Science Basic Research Plan in the Shaanxi Province of China (2016JM5036). The authors would like to acknowledge the Shandong Research Institute of Communications and volunteers for providing cooperation in the naturalistic driving test.

\section{REFERENCES}

1. Wang Y, Zhu H, Zhou F and Zhao Y.: "How driving duration influences drivers' visual behaviors and fatigue awareness: a naturalistic truck driving test study". Ethiopian Journal of Health Development, 32(1), 36-45, (2018)

2. Anund A, Fors C and Ahlstrom C.: "The severity of driver fatigue in terms of line crossing: a pilot study comparing day- and night time driving in simulator". European Transport Research Review, 9(2), 31, (2017).

3. Jin L, Niu Q, Jiang Y, Xian H, Qin Y and Xu M.: "Driver sleepiness detection system based on eye movements variables". Advances in Mechanical Engineering, 2013, 648431, (2013).

4. Cyganek B and Gruszczynski S.: "Hybrid computer vision system for drivers' eye recognition and fatigue monitoring". Neurocomputing, 126, 78-94, (2014).

5. Wang Y, Xin M, Bai H and Zhao Y.: "Can variations in visual behavior measures be good predictors of driver sleepiness? a real driving test study". Traffic Injury Prevention, 18(2), 132-138, (2017).

6. Wang Y, Ma C and Li Y.: "Effects of prolonged tasks and rest patterns on driver's visual behaviors, driving performance, and sleepiness awareness in tunnel environments: a simulator study”. Iranian Journal of Science and Technology, Transactions of Civil Engineering, 42(2), 143-151, (2018).

7. Kar S, Bhagat M and Routray A.: "EEG signal analysis for the assessment and quantification of driver's fatigue". Transportation Research Part F: Traffic Psychology and Behaviour, 13(5), 297-306, (2010).

8. Azim T, Jaffar MA and Mirza AM.: "Fully automated real time fatigue detection of drivers through Fuzzy Expert Systems". Applied Soft Computing, 18, 25-38, (2014).

9. Jagannath $\mathrm{M}$ and Balasubramanian V.: "Assessment of early onset of driver fatigue using multimodal fatigue measures in a static simulator". Applied Ergonomics, 45(4), 1140-1147, (2014).

10. Lawoyin S, Fei DY and Bai O.: "Accelerometer-based steering-wheel movement monitoring for drowsy-driving detection". Proceedings of the Institution of Mechanical Engineers, Part D: Journal of Automobile Engineering, 229(2), 163-173, (2015).

11. Hoddes E, Zarcone V, Smythe1 H, Phillips R and Dement WC.: "Quantification of sleepiness: a new approach". Psychophysiology, 10(4), 431-436, (1973).

12. Wang Y, Li L and Prato CG.: "The relation between working conditions, aberrant driving behaviour and crash propensity among taxi drivers in China". Accident Analysis \& Prevention, doi: 10.1016/j.aap.2018.03.028, (2018).

13. Hjälmdahl M, Krupenia S and Thorslund B: "Driver behaviour and driver experience of partial and fully automated truck platooning - a simulator study”. European Transport Research Review, 9(1), 8, (2017).

14. Bener A, Yildirim E, Özkan T and Lajunen T.: "Driver sleepiness, fatigue, careless behavior and risk of motor vehicle crash and injury: population based case and control study". Journal of Traffic and Transportation Engineering (English Edition), 2017;4(5), 496-502, (2017).

15. Kureckova V, Gabrhel V, Zamecnik P, Rezac P, Zaoral A and Hobl J.: "First aid as an important traffic safety factor - evaluation of the experience-based training”. European Transport Research Review, 9(1), 5, (2017). 


\section{LIST OF FIGURES AND TABLES}

Fig. 1. Illustration of driving test route in Shandong, China

Rys. 1. Ilustracja drogi pokonywanej podczas egzaminu na prawo jazdy w Shandong, Chiny

Fig. 2. Rate of change of driver's eye fixation behaviour

Rys. 2. Tempo zmian w skupieniu wzroku kierowcy

Fig. 3. Rate of change of driver's eye saccade behaviour

Rys. 3. Tempo zmian w ruchu gałek ocznych kierowcy

Fig. 4. Rate of change of driver's eye blinking behaviour

Rys. 4. Tempo zmian w mruganiu oczami kierowcy

Fig. 5. Rate of change of driver's subjective level of fatigue

Rys. 5. Tempo zmian w subiektywnym poziomie zmęczenia kierowcy

Table 1. The Standford Sleepiness Scale (SSS)

Tabela 1. Skala Senności Stanford (SSS)

Table 2. Predictor of driver fatigue via visual behavior variables

Tabela 2. Czynnik prognostyczny zmęczenia kierowcy poprzez wizualne zmienne zachowania 


\title{
AUTOMATYCZNA OCENA ZMECCZENIA KIEROWCY Z WYKORZYSTANIEM WIZUALNYCH ZMIENNYCH ZACHOWANIA
}

\author{
Slowa kluczowe: kierowcy zawodowi, wizualne zachowania, poziom zmęczenia, Skala Senności Stanford, czynnik \\ prognostyczny zmęczenia kierowcy
}

\section{PODSUMOWANIE:}

Kierowcy zawodowi spędzają długie godziny za kierownicą i szybciej odczuwają zmęczenie podczas prowadzenia pojazdu. $Z$ tego powodu, identyfikacja poziomu zmęczenia w czasie rzeczywistym ma kluczowe znaczenie dla zapewnienia bezpieczeństwa ruchu drogowego i zapobiegania wypadkom, w szczególności w odniesieniu do osób zajmujących się dalekobieżnym transportem komercyjnym. Łącznie 26 kierowców zawodowych w czterech grupach wiekowych zostało zaproszonych do udziału w naturalistycznym egzaminie na prawo jazdy, podczas którego każdy uczestnik został poproszony o ukończenie 2-godzinnych, 3-godzinnych i 4-godzinnych zadań związanych z prowadzeniem pojazdu, obejmujących przerwę na odpoczynek, na trzech drogach ekspresowych w Shandong, Chiny, celem zarejestrowania zmiennych skupienia wzroku, ruchu gałek ocznych i mrugania oczami, jak również subiektywnego poziomu zmęczenia. Następnie, zastosowano jednoczynnikową analizę wariancji w celu przeanalizowania zmienności każdego wizualnego wskaźnika według grup wiekowych w czasie, a analiza statystyczna wykazała, że nieprzerwana jazda ma istotny wpływ na zmiany wskaźników wizualnych i zgłaszany poziom zmęczenia. Po 2 godzinach prowadzenia pojazdu, zarówno średnia wartość czasu zamknięcia, jak i średni subiektywny poziom zmęczenia uległy znacznej zmianie. Po 4 godzinach prowadzenia pojazdu, wszystkie wizualne wskaźniki kierowcy, inne niż średnia liczba ruchów gałek ocznych i średnia średnica źrenicy, uległy znaczącej zmianie. Z drugiej strony, zmiana poziomu zmęczenia jest dodatnio związana ze zmianą średnicy źrenicy, czasem skupienia wzroku, częstotliwością mrugania, czasem mrugania i czasem zamknięcia. Z drugiej strony, zmiana poziomu zmęczenia była ujemnie związana z ilością skupień wzroku, kątem poszukiwań, liczbą ruchu gałek ocznych, szybkością ruchu gałek ocznych i amplitudą ruchu gałek ocznych. Mówiąc dokładniej, ruch gałek ocznych kierowcy był bardziej czuły na poziom zmęczenia podczas jazdy, a u osób starszych występowało większe prawdopodobieństwo, że wpłynie to na długość jazdy w zmienności zachowań wizualnych i uczucie zmęczenia. W przypadku kierowców zawodowych, przepisy ruchu drogowego powinny ściśle kontrolować długość nieprzerwanej jazdy, a osoby starsze powinny zyskać więcej czasu na odpoczynek. Wreszcie, czynnik prognostyczny zmęczenia kierowcy został określony poprzez zmianę współczynnika wizualnych zmiennych, w celu wykrycia poziomu zmęczenia i ostrzegania w krytycznym momencie, w czasie rzeczywistym. 